\title{
Pedagogical Training of Medicine Professors
}

Nilce Maria da Silva Campos Costa ${ }^{1}$

This study examines the pedagogical training process of medical professors at a Brazilian university, the meanings attributed to it, and the positive and negative aspects identified in it. This is a descriptive-exploratory study, using a qualitative approach with a questionnaire utilizing open-ended and closed questions and a semi-structured interview. The majority of queried individuals had no formal teacher training and learned to be teachers through a process of socialization that was in part intuitive or by modeling those considered to be good teachers; they received pedagogical training mainly in post-graduate courses. Positives aspects of this training were the possibility of refresher courses in pedagogical methods and increased knowledge in their educational area. Negative factors were a lack of practical activities and a dichotomy between theoretical content and practical teaching. The skills acquired through professional experience formed the basis for teaching competence and pointed to the need for continuing education projects at the institutional level, including these skills themselves as a source of professional knowledge.

Descriptors: Education; Higher Teaching; Education, Medical.

${ }^{1}$ Ph.D. in Education, Faculty, Faculdade de Nutrição, Universidade Federal de Goiás, Brazil, e-mail: nilce@fanut.ufg.br.

Corresponding Author:

Nilce Maria da Silva Campos Costa

Faculdade de Nutrição. Universidade Federal de Goiás

Rua 15, 220/1000

Setor oeste

CEP: 74140-035 Goiânia, GO, Brasil

E-mail: nilce@fanut.ufg.br 


\section{Formação pedagógica de professores de medicina}

Este estudo objetivou investigar a formação pedagógica de professores de medicina de uma universidade brasileira em relação à realização, tipo, pontos positivos e negativos e saberes presentes na formação. Trata-se de estudo descritivo-exploratório, com abordagem qualitativa que utilizou como instrumentos de coleta de dados questionário com questões abertas e fechadas e entrevista semiestruturada. A maioria dos pesquisados não teve capacitação em docência, mas recebeu alguma formação em disciplinas pedagógicas, cursadas em pós-graduação. Os pontos positivos citados foram a atualização em métodos pedagógicos e a ampliação da compreensão da área educativa, e os negativos foram pequena carga horária, falta de atividades práticas e dicotomia entre conteúdo teórico e ensino médico. Com base nos resultados, o estudo constatou a importância dos saberes da experiência na formação pedagógica dos professores estudados e apontou a necessidade de projetos institucionais de desenvolvimento docente que os considere como fonte de conhecimento profissional.

Descritores: Educação Superior; Ensino; Educação Médica.

\section{La formación pedagógica de profesores de medicina}

Este estudio tuvo por objetivo investigar la formación pedagógica de profesores de medicina de una universidad brasileña en relación a la realización, tipo, puntos positivos y negativos y conocimientos presentes en la formación. Se trata de estudio descriptivo y exploratorio, con abordaje cualitativo que utilizó como instrumentos de recolección de datos un cuestionario con preguntas abiertas y cerradas y entrevista semiestructurada. La mayoría de los investigados no tuvo capacitación en docencia, sin embargo recibió alguna formación en disciplinas pedagógicas, cursadas en posgraduación. Los puntos positivos citados fueron la actualización en métodos pedagógicos y la ampliación de la comprensión del área educativa, y los negativos fueron pequeña carga horaria, falta de actividades prácticas y dicotomía entre contenido teórico y enseñanza médica. Con base en los resultados, el estudio constató la importancia de los conocimientos de la experiencia en la formación pedagógica de los profesores estudiados y apuntó la necesidad de realizar proyectos institucionales de desarrollo docente que los considere como fuente de conocimiento profesional.

Descriptores: Educación Superior; Ensenãnza; Educación Medica.

\section{Introduction}

There are two conceptions of pedagogical training for university professors: the non-professional and the

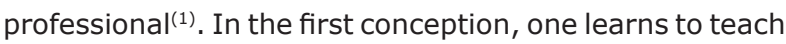
by teaching, from a simplistic view that reduces teacher training to the reproduction of pre-existing models. The second holds that achieving effective teaching is a complex task and a great social challenge with intellectual demands, and that teaching requires basic skills that can be acquired, improved and broadened through a continuing educational process.

Teaching in the medical area is restricted to the reproduction of previously acquired models that are considered valid and to practical everyday experience(2-3). This is a reflection of non-professional training, acquired non-reflectively as if it were something natural and just common sense, and seems to be widely accepted by professors, since it escapes criticism and is transformed into a spontaneous and generalized concept of what teaching is ${ }^{(4-5)}$.

Studies carried out with professors of medicine reveal that teaching is considered to be a secondary activity in relation to the medical profession itself and 
that the doctor's work as a professor is not considered a profession(2). In general, medical professors are considered good professionals in their specific area and the hiring criteria in higher education, in general, are centered on the quality of their technical competence ${ }^{(2,6-8)}$.

Only recently have university professors started to become aware that teaching, like research and the practice of any profession, demands training(9-10). In addition to the specific competencies for exercising a profession, there are the competences which relate specifically to the university professor, such as mastery of a particular area of knowledge, mastery of the pedagogical area and exercising the political dimension of university teaching ${ }^{(10)}$.

The teaching staff is the foundation on which the changes necessary for training health-area professionals should be instituted, and pedagogical practice has been a relevant research topic in the areas of nursing(11-15), dentistry(16) $^{(16)}$ medicine(17). Several authors have recognized the need for changes in health teaching practice and the need to train reflective teachers has been debated in health-area courses with a long tradition of discussion about teaching ${ }^{(17-18)}$. For nursing teachers, faculty training is understood as a complex and continuous process of technical, theoretical and pedagogical preparation(14-15).

This study scrutinizes the pedagogical training process of medical school professors at a Brazilian public federal university, the meanings attributed to it, and the positive and negative aspects identified in pedagogical training, in order to enrich and maximize the potential of teacher training.

\section{Methods}

A qualitative study was carried out with professors of medicine working at the undergraduate level, a criterion for inclusion in the study. Data collection instruments included one questionnaire with open and closed questions and a semi-structured interview. The questionnaire was organized to identify length of teaching time, academic qualifications, classes taught, medical school working conditions, teacher training, positive and negative experiences at the beginning of their careers and workplaces, among other matters. This first phase of research was used for accumulating data(19).

The interview, whose script was not known by the subjects in advance, sought answers to questions suggested by the teachers' own narratives ${ }^{(20)}$. Subjects' identities were preserved through the use of the word Teacher, with an ordinal and sequential number.

The study was carried out in stages: in the first stage, the questionnaire was given to those faculty members who attended the study site when data were collected. Of the 53 teachers who volunteered to participate in the investigation (50\% of the total) and answered the questionnaire, 35 (66\%) decided to participate in the second stage of the study, the semistructured interview.

Interview data were audio-recorded, transcribed literally and submitted to thematic content analysis according to Bardin(21). The understanding and interpretation of these data served to complement the data obtained from the questionnaires ${ }^{(22)}$.

The descriptive-analytical reading of the interview data involved four stages: exhaustive reading of the interviews, organization of the information, systematization of the data and construction of dialogs between data and literature(22).

The research project was submitted to and approved by the Ethics Committee at the Clinical Hospital of the university where the research was carried out. Data collection began only after the teachers had signed informed consent forms.

\section{Results}

The majority $(66 \%)$ of the 53 professors who participated in the study were males, between 36 and 55 years of age, $37.74 \%$ had up to 9 years and $56.6 \%$ from 10-29 years of teaching experience, $92.5 \%$ worked 20 or 40 hours per week and only $5.7 \%$ taught exclusively.

Of the 35 professors interviewed, $62.86 \%$ had no teacher training at the beginning of their careers. In the words of one of them 'I played it by ear', as these additional excerpts attest: I had no teaching experience (Teacher 4). It was acquisition through experience, self-teaching (Teacher 32). More improvisation. No theoretical basis (Teacher 8). I did things more intuitively (Teacher 25). I' $m$ sort of selftaught (Teacher 26). We didn't have teacher training .Our training is medical (Teacher 5).I had medical training, but I had no teacher training. I went along by trial and error (Teacher 31). I enjoy teaching a lot. So $I$ think it is by affinity and experience (Teacher 35).

There are professors who only acquired an awareness of their lack of teacher training after years of work at the university: Today I think to myself: I didn' $t$ know that I didn't have the training or qualifications (Teacher 30).

It became clear that the professors under study 
learned to be teachers through a partly intuitive selfteaching socialization process or by following what were considered model professors. The knowledge acquired through professional experience formed the basis for teaching competence: I think that my frustrations and those of students I am dealing with help us to see the best way to proceed (Teacher 35 ).

Despite the lack of training at the beginning of their careers, $71.7 \%$ (38 professors) mentioned having had, after a varying periods of university experience, some type of teacher training. Classes from the pedagogical area, taken in Stricto sensu post-graduate programs (55.3\%) predominated, an experience considered positive by the majority of the professors: We had teaching methodology. That's where you see all the mistakes that you make (Teacher 4). After I did the Master's, lots of things changed because I have methods now, I have training (Teacher 12). In my Master's I had didactics, I had pedagogy [...] they were required classes. [...] And I think it was great (Teacher 34).

Among the in-service courses to which the teachers referred $(21,1 \%)$, those most frequently mentioned were short courses promoted by the administrators of the medical school: I took some courses [...] Seminars about student and professor behavior; the way to get students to solve problems rather than having us give the solutions (Teacher 6). I thought the classes I took at the time were quite interesting, considering how to evaluate the student, the methodology of giving class (Teacher 27). I took a class here, just a one-day class, with a teacher from [...] who came here [...]. I loved it. He made some points, and I even said: "Wow, this is different from everything I do'. Through all of these things, we change the way we teach (Teacher 28).

Another type of teacher training mentioned was the required course for new professors at the university. It is noteworthy that some subjects have specific degrees in education, such as the three (7.9\%) with a Master's degree and two (5.3\%) who have a specialization in this area.

The teachers related their experiences of the difficulties stemming from their lack of pedagogical training and the suffering that this fact caused some of them: I suffered a lot from the lack of experience, the lack of preparation as a teacher. I had experience only as a doctor. I didn't have teaching techniques, testing, the technical part of teaching. (Teacher 3). I had trouble making a lesson plan, I didn't know what a course plan was, I didn't know how to fill out a diary, those basic things in teaching (Teacher 1). The main difficulty is precisely the lack of teacher training (Teacher 8). That's exactly it, you start out thinking " If I know the content,
I know how to teach the content". It took me years, and in the first few years I must merely have reproduced the information that I had (Teacher 13). The fact that we don't have teacher training is a problem for us. We wind up being doctors who teach. (Teacher 27). The hardest thing is how would I transmit that knowledge, how do I take that knowledge to the student (Teacher 29).

The professors interviewed were clear about the important role that teacher training plays in their performance: I think one thing is super-important. because for me it's one of the omissions of medicine, this teacher training that we don't have (Teacher 4). I think that for us to teach, we really needed to have this training when we are in graduate school (Teacher 27). I don't believe that an individual, just because he is a doctor and has undeniable competence in the area of medicine, that this is enough for him to understand teaching. (Teacher 12). I think that to give classes, the individual has to be adequately trained. (Teacher 5)

\section{Positive and negative factors in teacher training}

Those professors who had some kind of " formal" teacher training were asked about positive and negative points. The main positive point, mentioned by $71.11 \%$, was the possibility of being updated on teaching methods (teaching techniques/methods, the teachinglearning process, communication, learning evaluation and teacher-student relations). It is worth noting that this training prioritizes the technical side of the process rather than reflection about the practices the teacher is using.

Despite this observation, $22.23 \%$ of the professors believe they broadened their understanding of the area of education. It was clear that some of the professors interviewed had reflected on their personal experience and given it meaning: I realized that education is an area of specialization and that it must not be improvised (Teacher $5)$. These courses helped me a lot, of course, because there you start to understand the mechanics of being a teacher. It's different from the professional's daily practice (Teacher 11). A moment of reflection on the practice of teaching (Teacher 4). A better understanding of medical teaching and learning (Teacher 2).

Eight-five percent of the professors considered the small number of education classes as the main negative point, a reflection of the desire to increase their knowledge in this area: I took two classes during my doctorate, but I still don't think it was enough (Teacher 4).

Other negative factors reported were a lack of practical activities in the courses (25\%) and a gulf between class content and medical teaching (14.29\%) 


\section{Discussion}

The first point to be made in this study is the strong presence of experience-derived knowledge in medical teaching. From the words used to refer to this training, 'acquisition through experience', 'self-taught', 'improvisation', 'intuitively', 'trial and error', and 'affinity', it is obvious that teacher training occurs as a process based in professional practice.

Knowledge derived from practice or experience is not systematized and represents how the professors interpret and direct their daily teaching practice(23). This type of training is not considered the best, since educational improvisation is the best way of perpetuating the limitations of an obsolete method ${ }^{(24)}$. This is because it limits discussion and reflection on teaching practice and does not permit an explanation of the practices adopted, in addition to not permitting theoretical enrichment through reading and a broadening of the teacher's view of the world. In this way, the practical character of experience-derived knowledge is reduced to the individual sphere, and cannot be shared.

The teachers'autodidactic ability is important, but cannot be considered sufficient. For this author, knowledge derived from experience is generally undervalued and even ignored by educational institutions and by the teachers themselves as a source of professional knowledge.

Since teaching skills are constructed over a professional's career, the nature of these skills is difficult to isolate, since they are largely implicit and not only involve theories and concepts based on courses systematized knowledge - but are also influenced by personal knowledge acquired through experience. While it is easy to separate them for descriptive purposes, they are intertwined in professional practice and are inseparable.

With training obtained through experience, the professors under study tend to limit their world of action to their classes. Teaching activity, however, requires the ability to problematize visions of teaching practice, the role of the teacher and the purpose of higher education. This presupposes that each teacher should analyze the political, cultural and economic meaning involved in the course, the way in which the teaching role is assimilated, and how the ideological patterns which form the basis of the educational structure are internalized.

A second point is the limited value placed by the institution on the pedagogical training of the professor of medicine. This can be attributed to the undervaluing of teaching activity at universities, since the stimuli to action and the criteria for advancement in a teaching career are based more on scientific production than on the exercise of teaching $(2,9,24)$.

This point leads us to insist on the proposition that pedagogical training, which is recognized by the interviewees as extremely relevant to their teaching work, needs to be adopted as a priority by medical schools. They should provide continuing education courses and require the professors' participation in them, for example. Just as a doctor needs to have a Master's degree or doctorate in some area of medical science to be a professor, professors should be required to continue their pedagogical training by participating in relevant courses that integrate theory and practice.

Another initiative could be to encourage, value, and create opportunities to accompany innovative projects in the area of medical teaching involving teams of teachers from the same or similar areas: teams of professors of different subjects, but who work with the same class of students and are willing to plan an integrated course. Teachers need to feel support and interest on the part of the employing institution in improving medicine courses through an advancement in the quality of learning by future doctors. They need to realize that they have colleagues interested in modifying their classes and making them true learning environments for their students and that, together with other colleagues, they want to offer teaching that is different and better than what they have been providing.

For this reason, pedagogical training needs to be thought out, budgeted for, and prioritized in the university context. Time to carry out these activities must also be assured. The training process should be dynamic and continuous, leading to the elucidation of problems, rather than the customary scapegoating. On the contrary, partnerships, co-responsibilities and the integration of pedagogical and scientific competencies of those involved need to be a priority.

A third point relates to the pedagogy classes offered in post-graduate programs. A significant number of interviewees underscore how important these postgraduate pedagogy classes were for their teaching work. This information should remind post-graduate course coordinators of the fact that, by law, post-graduate courses must train not only researchers, but also university-level teachers.

This last function, when dealt with in a post-graduate course, is limited to a few pedagogy class sessions; the participants in this study affirm that they were 
of considerable value to them. Have the coordinators of these courses thought about how they could do a better job of preparing professors if they developed a curriculum that trained researchers and teachers at the same time?

It is desirable for professors to transcend the limits that circumscribe their work and go beyond a merely technical vision of teaching, in which the only problems are those of meeting the goals determined by the institution. In addition to routine activities of a technicalrational order, the professor lives in a context of decisionmaking, which makes it possible to characterize him as a reflective professional(25).

From the dialogue between experiences and information, and between professors of various medical subjects, a teaching practice that meets the current professional development needs of the health sector may be developed. The teachers need a global view of teaching and their new roles as mediators and facilitators in the learning process. To be effective teachers requires skills such as facilitative learning, teaching in small groups, assessing learners, and providing feedback ${ }^{(26)}$.

The reflections on pedagogy emerging from the studied group about teaching methodology effected the performance of the involved faculty and brings into sharp relief the fact that the collective process must be continuous in order to support the pedagogical development of these professionals, who are educational agents for the improvement of the formation of medical and other health professionals.

\section{Conclusion}

This study scrutinizes the pedagogical training process of medical school professors at a Brazilian public federal university, and acknowledges the strong presence of knowledge derived from experience in medical teaching. Among the professors who had some kind of "formal" teacher training, the main positive point was the possibility of being updated regarding teaching methods. It is worth noting that this training prioritizes the technical side of the process rather than reflection about the practices the teacher is using.

The training of the professors of medicine who participated in this study has been permeated by battles that each of them had to wage on his own through a slow and uncertain self-training process. In some cases, erroneous views concerning what it means to teach at a university are solidified, not because of individua incompetence, but rather due to the lack of opportunities for correct professional development. In other cases, teachers who believe that they are unable to develop appropriate teaching competences proceed down an undemanding professional development path.

Thus, one of the most important items for improving medical school teaching is to plan pedagogical training that integrates teaching experience with discussion of the relevant principal educational theories in order to help the professors critically analyze their teaching practices and experiences and find new and better ways of teaching.

Professors of medicine should be invited to participate in the creation and construction of a new consciousness. It is necessary to revisit the 'whats' and 'hows' of being a teacher on the basis of a process of personal reflection on personal experience. It is necessary to develop a conscious educational process that develops the teacher's potential and problemsolving capabilities based on the conjugation of beliefs, values and knowledge.

In this paper, real-world data have been obtained that can sustain a rethinking of and/or respecification of the pedagogical practice of teachers in the health area working at the undergraduate level.

\section{References}

1. Zabalza MA. O ensino universitário: seu cenário e protagonistas. São Paulo (SP): Artmed; 2004.

2. Batista NA, Souza SH. A função docente em medicina e a formação/educação permanente do professor. Rev Bras Educ Med 1998; 22:31-6.

3. Batista N, Batista SH. A docência em saúde: desafios e perspectivas. In: Batista N, Batista SH, organizadores. Docência em saúde: temas e experiências. São Paulo (SP): Senac; 2004. p.17-31.

4. Perrenoud P. A formação dos professores no século XXI. In: Perrenoud P, Thurler, MG . Porto Alegre (RS): Artmed; 2002. p. 11-31.
5. Carvalho AMP. Paradigmas e métodos de investigação nas práticas de ensino: aspectos epistemológicos. Anais do VII Encontro Nacional de Didática e Prática de Ensino; 1994; Goiânia (GO); 1994. p. 79-90.

6. Bireau A. Novas funções atribuídas à universidade. In: Bireau A. Os métodos pedagógicos no ensino superior. Porto: Porto Editora; 1995. p.22-9.

7. Mcleod PJ, Steinert Y, Meagher T, Mcleod A. The ABCs of pedagogy for clinical teachers. Med Educ 2003; 37:638-44.

8. Mclean M. Reawarding teaching excellence. Can we measure teaching "excellence"? Who should be the judge? Med Teach $2001 ; 23: 6-11$. 
9. Abreu MC, Masetto MT. Ensino e aprendizagem. In: Abreu MC, Masetto MT. O professor universitário em aula: prática e princípios teóricos. São Paulo (SP): MG Editora Assoc; 1997. p. 3-12.

10. Masetto MT. Professor universitário: um profissional da educação na atividade docente. In: Masetto MT. Docência na Universidade. Campinas (SP): Papirus; 1998. p. 9-26.

11. Guariente MHD, Berbel NAN. A pesquisa participante na formação didático-pedagógica de professores de enfermagem. Rev Latino-am Enfermagem 2000; 8(2): 53-9.

12. Pinto JBT, Pepe AM. Nursing education: contradictions and challenges of pedagogical practice. Rev Latino-am Enfermagem 2007; 15(1):120-6.

13. Rozendo CA, Casagrande LDR, Schneider JF, Pardini LC. Uma análise das práticas docentes de professores universitários da área de saúde. Rev Latino-am Enfermagem 1999; 7(2):15-23.

14. Alencar NG, Batista SHS, Ruiz-Moreno L. Women's health education in undergraduate nursing courses. Rev Latino-am Enfermagem, 2007; 15(2):355-7.

15. Figueroa AA. A inovação da educação superior em Enfermagem e os aportes do desenho da instrução. Rev Latinoam Enfermagem 1999; 7(2):5-13.

16. Secco LG, Pereira MLT. Formadores em odontologia: profissionalização docente e desafios político-estruturais. Cienc Saúde Coletiva 2004; 9(1):113-20.
17. Lampert J. Tendências de mudança na formação médica no Brasil: tipologia das escolas. São Paulo: Hucitec; 2002.

18. Faria JIL, Casagrande LDR. A educação para o século XX e a formação do professor reflexivo na enfermagem. Rev Latino-am Enfermagem 2004; 12(5):111-8.

19. Estrela A. [Introdução]. In: Estrela A. Teoria e prática de observação de classes: uma estratégia de formação de professores. Porto: Porto Editora; 1994. p. 11-24.

20. Turato ERT. Tratado da metodologia clínico-qualitativa. Petrópolis (RJ): Vozes; 2003.

21. Bardin L. Análise de conteúdo. Lisboa: Edições 70; 1977.

22. Minayo MCS. O desafio do conhecimento: pesquisa qualitativa em saúde. São Paulo (SP): Hucitec-Abrasco; 1992.

23. Tardif M, Lessard C, Lahaye L. Os professores diante do saber: esboço de uma problemática do saber docente. In: Tardif M. Saberes docentes e formação profissional. Petrópolis (RJ): Vozes; 2002. p.31-55.

24. Venturelli J. Educación médica: nuevos enfoques, metas y métodos. Washington (DC): OPS; 1997.

25. Ministério da Educação (BR). Conselho Nacional de Educação. Resolução no 4, de 01 novembro de 2001. Diretrizes Curriculares Nacionais do Curso de Graduação em Medicina. Brasília; 2001.

26. Clark JM, Houston TK, Kolodner K, Branch W, Levine R, Kern DE. Teaching the teachers. J Gen Int Med 2004; 19:205-19.

Received: Sep. $8^{\text {th }} 2008$

Accepted: Sep. 15 2009 